\title{
ARTICLE 9 OF THE UNIFORM COMMERCIAL CODE: ELECTION OF REMEDIES ON DEFAULT
}

$\mathbf{S}_{\text {Ection 9-5oI of the Uniform Commercial Code }}$ provides that the secured creditor can enforce his rights on default of the security agreement by reducing his claim to judgment and that, if the collateral is goods, the creditor may "do one or more of the following": foreclose the security interest by judicial proceeding or take possession of the collateral. ${ }^{2}$

In In the Matter of Adrian Research and Chemical Company, ${ }^{3}$ the court was called upon to interpret section 9-50I to determine whether the doctrine of election of remedies ${ }^{4}$ is applicable under it.

On September 10, 1957, the Adrian Research and Chemical Company executed a security agreement in favor of the petitioner in consideration of certain rent arrearages. This security agreement, creating a mortgage on office fixtures and plant equipment, was duly recorded. ${ }^{5}$ Contemporaneously, the debtor executed a cognovit note in a sum equal to the amount of rent arrearages, payable on demand, upon which judgment was entered two days later. When the debtor subsequently defaulted in the payment of current rent, execution was issued on the judgment and the sheriff, on March 12, 1958, levied on the collateral and posted bills for sale. Shortly thereafter, on March 27, 1958, a voluntary petition in bankruptcy was filed by the debtor and a receiver was appointed. The receiver immediately obtained an order restraining. the sheriff's sale, whereupon the petitioner sought to recover possession of the collateral. On these facts the court held that the secured creditor could not take possession of collateral under a security agreement after he had obtained a judgment, issued execution, and caused a levy to be made.

\footnotetext{
${ }^{2}$ PA. STAT. tit. I2A (1954).

169 F. Supp. 357 (E.D. Pa. 1958).

- "The doctrine stated in its simplest form means that, if a party has two inconsistent existing remedies on his cause of action and makes choice of one, he is precluded from thereafter pursuing the other." Henderson Tire \& Rubber Co. v. Gregory, 16 F.2d 589, 593 (8th Cir. 1926). See also, Klinger v. Modesto Fruit Co., Io7 Cal. 97, 290 Pac. 127 (1930); Hannigan v. Itala-Petroleum Corp. of America, 7 Del. 180, I81 Atl. 4 (1935); Schmidt v. Johnston, 154 Md. 125, 140 Atl. 87 (1928); City of Kirkwood v. Martin, 219 Mo. App. 490, 282 S.W. 542 (1926); Johnson v. White, 17 I Tenn. 536 , 006 S.W.2d 222 (1937).

BA. Stat. tit. 12A; § 9-401 (1954).
} 
In reaching its decision, the court acknowledged that the creditor's remedies upon default were cumulative, but it held that they must have been consistent as well. ${ }^{6}$ Since the judgment lien was invalid as against the trustee in bankruptcy, having been perfected within four months of the filing of the petition in bankruptcy, ${ }^{7}$ and since Pennsylvania recognizes no judicial procedure by which a security interest in personal property can be foreclosed, ${ }^{8}$ the petitioner's only alternative was to acquire possession of the collateral. But the Pennsylvania court held that the right to take possession was inconsistent with judgment, execution, and levy. ${ }^{9}$ That is, the petitioner, by obtaining judgment and execution, affirmed ownership in the Adrian Research and Chemical Company, an affirmation repugnant to a claim of ownership in himself. ${ }^{10}$

When considering the doctrine of consistency of remedies of a secured creditor, the jurisdictions of this country may profitably be divided into two general categories: those which have enacted the Uniform Conditional Sales Act, and those which have not. Jurisdictions following the Uniform Conditional Sales Act ${ }^{11}$ have generally held that recovery of collateral by a secured creditor is not inconsistent with an

\footnotetext{
-The doctrine of conclusive election of remedies does not apply where the available remedies are cumulative and consistent. Pierce v. United States, 255 U.S. 398 (1921); Zimmerman v. Harding, 227 U.S. 489 (1913); Toner v. Conqueror Trust Co., 126 Kan. 554, 268 Pac. 810 (1928); Washburn v. Peck, 245 Mich. 351, 222 N.W. 768 (1929); Rosacker v. Commercial State Bank, I91 Minn. 553, 254 N.W. 824 (1934); Nettles v. Sottile, 184 S.C. r, 19r S.E. 796 (1937).

${ }^{7}$ See ir U.S.C. § $107\left(193^{8}\right)$.

The problem of the instant case has been alleviated by a subsequent revision in the official text of the Uniform Commercial Code made in 1957. UNIFOrM Commercial CODE $\S$ 9-501 (5) provides: "When a secured party has reduced his claim to judgment the lien of any levy which may be made upon his collateral by virtue of any execution based upon the judgment shall relate back to the date of the perfection of the security interest in such collateral." This provision was incorporated by the Kentucky legislature when it adopted the Uniform Commercial Code. See, Ky. Acts 1958, ch. 77, Senate Bill No. 169 .

${ }^{8} 169$ F. Supp. at 359.

${ }^{\circ}$ Citing In re Fitzpatrick, I F.2d 445 (W.D. Pa. 1923); In re Elkins, 38 F. Supp. 250 (E.D. Pa. 1941).

${ }_{10}$ "To determine whether coexistent remedies are inconsistent, the relation of the parties with reference to the right sought to be enforced as asserted by the pleadings should be considered." American Process Co. v. Florida White Pressed Brick Co., 56 Fla. 116, 122, 123, 47 So. 942, 944 (1908). Accord, Capital City Bank v. Hilson, 64 Fla. 206, 60 So. 189 (1932); Nelson v. Jardine, 46 Idaho 82, 267 Pac. 447 (x928); Scott v. McIntosh, 167 S.C. 372, 166 S.E. 345 (1932); Rowell v. Smith, 123 Wis. 510 , 102 N.W. I (1905).

${ }^{12}$ Alaska, Arizona, Delaware, Hawaii, Indiana, New Hampshire, New Jersey, New York, Pennsylvania, South Dakota, West Virginia, and Wisconsin. See 2 U.L.A. (Supp. 1958).
} 
action for the debt until the debt is recovered. ${ }^{12}$ In such a jurisdiction, adoption of the Uniform Commercial Code presumably would not change the law, and a secured creditor could still claim possession of the collateral after having brought an action for the debt at any time before recovery of the debt.

A majority of those jurisdictions ${ }^{13}$ which have not enacted the Uniform Conditional Sales Act maintain that recovery of the collateral is inconsistent with an action for the debt, and, therefore, that the election of one remedy constitutes a waiver of the other. ${ }^{14}$ The effect of the Code in such jurisdictions is more conjectural. However, the use of the words "in addition" in section 9-50I of the Uniform Commercial Code would seem to imply that no election of remedy is made by the creditor until he has obtained satisfaction of his judgment against the debtor. Under such an interpretation of the Code, it seems likely that most courts would construe the remedies of recovery of security and action on the debt to be consistent, precluding operation of the election of remedies doctrine. Thus, a secured creditor would be empowered to recover the security notwithstanding commencement of a suit on the debt, a result, it is submitted, which would be desirable. ${ }^{15}$

Also of bearing in the instant question is section 9-202 of the Code, ${ }^{10}$

12 "It is clearly the contemplation of the Conditional Sales Law that the conditional vendor may bring an action for the recovery of the price and later retake possession ...." Allis-Chalmers Mfg. Co. v. Nein, 64 S.D. $235,238,266$ N.W. 156,158 (1936).

${ }^{18}$ See, e.g., Hollenberg Music Co. v. Barron, 100 Ark. 403, 140 S.W. 582 (1911), Boas v. Knewing, I75 Cal. 226, I65 Pac. 690 (1917); American Process Co. v. Florida White Pressed Brick Co., 56 Fla. 116, 47 So. 942 (1908); Frisch v. Wells, 200 Mass. 429, 86 N.E. 775 (1909); Norman v. Meeker, 91 Wash. 534, 158 Pac. 78 (1916).

A number of states, however, which have not enacted the Uniform Conditional Sales Act have held that an action on the debt and recovery of the collateral are not inconsistent remedies and apparently the trend of recent decision is toward this view. $C f$. Murray v. McDonald, 203 Iowa 418, 212 N.W. 711 (1927).

${ }^{14}$ For typical reasoning, see Eilers Music House v. Douglass, 90 Wash. 683, 685, 156 Pac. 937, 938 ( 1916$)$ : "In this state it is well settled that under a conditional sale contract the title to the article sold remains in the vendor, and on breach of the contract by the purchaser the seller has a choice of remedies. He may disaffirm the contract and retake the chattel, or he may treat the transaction as an absolute sale and sue on the contract. He cannot do both; these remedies are inconsistent. To proceed by one remedy constitutes an election which is final and irrevocable."

${ }^{15}$ The position of the secured creditor would be considerably improved in cases where the judgment he has obtained proves uncollectible as in the case of a supervening bankruptcy.

${ }^{16} \mathrm{PA}_{\mathrm{A}}$ StAT. tit. I2A, $\S 9-202$ (1954): "Title to Collateral Immaterial. Each provision of this Article with regard to rights, obligations and remedies applies whether title to collateral is in the secured party or in the debtor." 
which provides that title to collateral does not affect the rights, obligations, or remedies of the parties. It could be argued that this provision was intended to extinguish the anachronistic notion that a levy of execution is inconsistent with an action on the debt. ${ }^{17}$ The basis of this notion, after all, is that a levy in execution affirms ownership of the collateral in the debtor, and, consequently, that the creditor is precluded thereby from later asserting title in himself by attempting to claim possession of the collateral. Since section 9-202 abrogates nice distinctions turning on the concept of title, it follows that enactment of the Code should serve to displace the idea of inconsistency between levy in execution and recovery of collateral. In this regard, the instant decision seems to ignore a fundamental purpose of the Code.

It seems fair to assume, however, that future cases involving a similar question arising in other Code jurisdictions will be resolved differently and that the Uniform Commercial Code will be vindicated in its effort to eliminate the technical distinctions of title and to strengthen the position of the secured creditor with respect to his remedies against the debtor upon default of the security agreement.

\footnotetext{
17 'But since this Article adopts neither a 'title'. nor a 'Tien' theory of security interests ... the granting or denying of, for exasnple, petitions of reclannation in bankruptcy proceedings should not under it be influenced by speculations as to whether the secured party had 'title' to the collateral or 'merely a lien.'" Uniform Commetcial Code Comment, PA. Stat. tit. 12A, § 9-507 (1954).
} 